\title{
Studies on Cultural and Morphological Variability in Isolates of Exserohilum turcicum, Incitant of Turcicum Leaf Blight of Sorghum
}

\author{
M. R. Vinay* and A. R. Sataraddi
}

Department of Plant Pathology, College of Agriculture, Vijayapur, 586101, India University of Agricultural Sciences, Dharwad, 580001, Karnataka, India

*Corresponding author

\section{A B S T R A C T}

\section{Keywords}

Turcicum leaf blight, Exserohilum turcicum, Sorghum, Cultural variability

Article Info

Accepted:

04 November 2019

Available Online:

10 December 2019
Sorghum [Sorghum bicolor (L.) Moench] belongs to family Poaceae. It is termed, as 'poor man's crop' as it performs well even in marginal lands under moisture stress conditions, low availability of fertilizers and other inputs as compared to other crops. The foliar pathogens are potential yield reducers, and may cause substantial yield losses when occur in epidemic form. Leaf blight of sorghum caused by Exserohilum turcicum (Pass.) Leonard and Suggs is a major foliar disease, which substantially damages the foliage. The foliar blights and spots cause direct loss of foliage due to premature drying and early seedlings blights, or loss in other forage components like fodder weight and reduced carbohydrate translocation to other parts of plants due to reduced photosynthesis and transpiration. A total of 20 isolates of E. turcicum were obtained from district of Northern Karnataka. These isolates were grown in Potato Dextrose Agar (PDA). They varied in their cultural and morphological behaviour. All the isolates were found pathogenic to sorghum. The virulent isolate (E04) showed significant variations in colony colour, colony texture, surface and topography, margin, lustre, sporulation and consistency in the media viz., PDA, Malt extract Agar, Saboraud's Medium, Richard's Medium, Czapek's dox medium, Yeast extract mannitol agar and Oat meal agar. The maximum average growth of the isolate (E04) was supported by PDA medium $(7.35 \mathrm{~cm})$ whereas minimum growth was recorded in V-8 juice agar medium $(3 \mathrm{~cm})$. Conidia were observed in all the isolates except Et07, Et09 and Et17. Among the isolates, conidia size was maximum in isolate Et10 $(87.13 \times 12.31 \mu \mathrm{m})$ with an average of 7-10 septation and minimum in isolate Et14 (33.92 $\times 12.23 \mu \mathrm{m}$ ) with $3-4$ septation.

\section{Introduction}

Sorghum [Sorghum bicolor (L.) Moench] belongs to family Poaceae. It can be easily grown in latitudes ranging from $40{ }^{\circ} \mathrm{S}$ to 45 ${ }^{\circ} \mathrm{N}$. In India, it is mostly grown between $9^{\circ}$ and $21^{\circ}$ in tropical and sub-tropical climates. Important uses of sorghum include food in the form of unleavened bread or roti, boiled porridge or gruel, fodder, animal feed, building material and fibre, beer, malted beverages and popped grains. About 35-40 per 
cent of grain sorghum produced worldwide is consumed directly as food. Besides, it has several other industrial uses such as production of jaggery, syrup, lactic acid, riboflavin, microbial polysaccharides, antibiotics, ethanol and citric acid (Arun et al., 2009).

Yield of sorghum is generally low in tropical countries, where it is mostly cultivated by marginal farmers. Sorghum diseases are considered to be the major constraint in realizing proper yield potential (ICRISAT, 1980). Sorghum crop is attacked by a large number of diseases, infecting, grains, foliage and roots. Leaf blight of sorghum caused by Exserohilum turcicum (Pass.) Leonard and Suggs is a major foliar disease, which substantially damages the foliage. The pathogen exhibits good tolerance to varied ranges of agroclimatic conditions over the globe. The pathogen is worldwide in distribution; though varies in severity and prevalence in different regions, hence in the economic importance (Tarumoto et al., 1977).

The typical symptoms of leaf blight are long, 1-2 cm wide, elliptical, necrotic lesions, straw coloured in the centres with dark margin. The colour of the margin ranges from brown, red or purple depending upon host cultivar. Under humid conditions the centres of lesions bear faint to dark grey growth consisting of conidiophores and conidia. Many lesions may develop and coalesce on the leaves, destroying large areas of leaf tissue and giving the crop a distinctly burnt or blighted appearance (Bunker, 2005). Little information is available on the extent of losses caused by E. turcicum. Lee et al., (1986) observed 47 and 38 per cent reduction in fresh and dry matter yield due to leaf blight.

E. turcicum known to produce conidiophores which are single or in small groups, straight to flexuous, sometimes geniculate above, septate, smooth, mid to dark brown, up to $300 \mu \mathrm{m}$ long and 6-9 $\mu \mathrm{m}$ wide. Conidiogenous cells polytretic, integrated, terminal and intercalary, sympodial, cicatrized. Conidia pale to mid olivaceous brown, fusoid, smooth, straight or curved, mostly 4-7 septate, but up to10 distoseptate, measuring 100-135 x 15-25 $\mu \mathrm{m}$, with a small protruding basal hilum (Sivanesan, 1986).

E. turcicum is highly versatile to changing environmental conditions and shows high variability across different agro-climatic regions. Therefore, in order to document the changes occurring in populations and individuals, variability studies are important as it indicates different pathotypes and may open up a new avenue for disease management in the future. Variation in pathogen can be generally detected by their cultural and morphological characters.

\section{Materials and Methods}

\section{Collection of infected specimen and isolation of the fungus}

Sorghum leaves bearing typical symptoms of the turcicum leaf blight disease were collected at flowering/grain filling stage from farmer's field in 2017-18 growing seasons in Vijayapur, Dharwad, Bagalkot and Belagavi and used for the study.

The infected leaves samples were plucked and kept in polythene bags with labels. They were brought to laboratory for microscopic observation and later kept at $4^{\circ} \mathrm{C}$ for further studies.

\section{Isolation}

Sorghum leaves showing typical symptoms of turcicum leaf blight were collected from the field. Leaves with symptoms were first washed in tap water and then cut into small 
bits of $2 \mathrm{~mm}$ size, containing the discoloured blights. These bits were surface sterilized with 0.1 per cent $\mathrm{NaOCl}$ solution for two minutes followed by three changes of sterilized distilled water. These bits were placed on potato dextrose agar under aseptic condition.

Inoculated plates were incubated at $27^{\circ} \mathrm{C}$ and watched for any contamination for seven days. After seven days of incubation, fungal colonies completely covered the plates and become dark greyish in colour indicating the production of spores.

A small loop of fungal culture from the colonies was picked and slide was prepared by mixing the culture with a drop of lacto phenol. The slide was observed under low and high power objectives for the presence of conidia.

\section{Purification}

Purification of the fungus was done by single spore isolation techniques. The spore suspension of the fungal isolate was prepared in sterile distilled water. One $\mathrm{ml}$ of the suspension from fungal isolate was mixed with $20 \mathrm{ml}$ of molten two per cent water agar. Single spore was marked with ink under stereo binocular microscope.

The spore along with water agar was picked and transferred on potato dextrose agar plates and slants. Plates were incubated at room temperature $\left(27 \pm 1^{\circ}\right.$ C) and periodically observed for the germination of spores and pure culture thus obtained were designated as sorghum isolates and were preserved on potato dextrose agar slants in refrigerator for further studies.

\section{Identification}

The pathogen forms grey colonies on the Petri dishes containing PDA. The colonies appeared as whitish grey mycelial growth and turns dark grey with sporulation. Conidiophores were single or in small groups, straight to flexuous, septate, smooth, dark brown. Conidia pale to mid olivaceous brown, fusoid, smooth, straight or curved, mostly 4-7, but up to 11 distoseptate, measuring 100-135 x 15-25 $\mu \mathrm{m}$, with a small protruding basal hilum. On the basis of these characters the pathogen was identified as Exserohilum turcicum (Sivanesan, 1986).

\section{Proving pathogenicity}

Seeds of Sorghum from disease free plants of the previous season were surface disinfected with 0.1 per cent $\mathrm{NaOCl}$ for one minute and sown in pots containing sterilized soil in order to raise healthy seedlings.

The pathogen was multiplied by transferring a loopful of the stock culture to $250 \mathrm{ml}$ of potato dextrose broth taken in a $1000 \mathrm{ml}$ flask. The inoculated flask was incubated at $27 \pm 1^{\circ} \mathrm{C}$ for seven days. The fungal culture growing on potato dextrose broth was passed through double layered muslin cloth. The spore suspension of the pathogen was collected under aseptic condition in an automizer.

The spore suspension was collected separately in an automizer and sprayed on to the foliage at three to four leaf stage to susceptible sorghum variety M 35-1 at 105 spores per ml as suggested by Kadir et al., (2008) and Tosiah et al., (2011). Inoculated seedlings covered with polythene cover to create required moisture content for $24 \mathrm{hrs}$.

The seedlings after spray inoculation were kept in green house condition. Periodical observations were made for the development of typical brown spots on the inoculated plants. The pathogen from typical brown spots was re-isolated, compared with the original symptoms as well as published literature for confirmation. 
Cultural and morphological studies of $E$. turcicum

\section{Cultural studies of the pathogen}

\section{Effect of different media}

The study was conducted to describe the cultural characters such as colony colour, colony texture, surface topography, consistency, margin and lustre of the leaf blight pathogen on different solid media. $7 \mathrm{~mm}$ culture discs of pathogen was inoculated separately on different media viz., PDA, Malt extract Agar, Saboraud's Medium, Richard's Medium, Czapek's dox medium, Yeast extract mannitol agar and Oat meal agar, and incubated at $28 \pm 2{ }^{\circ} \mathrm{C}$ for 12 days. The cultural characters and the colony diameter $(\mathrm{mm})$ on each medium were recorded. Growth characters on PDA was taken as standard while making comparative studies on different media.

\section{Morphological Studies}

Data on radial colony growth of E. turcicum were obtained by multiplying vertical and horizontal growth of hyphea, measured with centimetre calibrated plastic ruler. The values were rated as excellent $\left(\geq 7.6 \mathrm{~cm}^{2}\right)$, good (6.6$\left.7.5 \mathrm{~cm}^{2}\right)$, moderate $\left(5.0-6.5 \mathrm{~cm}^{2}\right)$ and poor $(<$ $5.0 \mathrm{~cm}^{2}$ ) growth as described by Levy (1991) with modification. Conidial suspensions were prepared from 15-day-old cultures on infected sorghum seeds and adjusted to $10 \mathrm{conidia} / \mathrm{ml}$ based on counts made with a hemacytometer. Thereafter, $5 \mathrm{ml}$ of the conidial suspension were pipetted into a $9 \mathrm{~cm}$ petri dish containing potato dextrose agar. Inoculated plates were incubated for 24 hours under light and darkness at $25{ }^{\circ} \mathrm{C}$ and used for percentage germination based on 100 conidia per petridish. Temporary slides of each treatment were viewed under binocular Leica microscope at $40 \mathrm{x}$ and the sporulation were rated excellent for $\geq 20$ conidia per microscopic field (++++), good (15-20 conidia per microscopic field +++ ), fair (10-15 conidia ++ , poor $\leq 10$ conidia + ) and - for no sporulation, as described by Harlapur et al., (2007). To study morphological characters of conidia of all the isolates of Exserohilum turcicum, slides were prepared from twelve days old culture. Temporary slides were prepared in water mount using cotton blue. Data on length, width and septation of conidia were recorded by ocular micrometer by using a recalibrated compound microscope. 10 spores were observed for each isolate to avoid the error while taking observations.

\section{Results and Discussion}

Isolation and maintenance of different isolates of $E$. turcicum

The pathogen was isolated and the fungal cultures on purification showed white colour and fluffy type of mycelium, which gradually turned into greyish, greenish or brownish as the culture started to produce conidia. On repeated isolation, it was found the association of E. turcicum.

A total of twenty isolates were obtained and designated with isolate code as Et according to their respective places of collection (Table 1). The pathogen was identified by comparing with relevant literatures and by studying the cultural and morphological characters. The fungal isolate cultures were sub cultured frequently on PDA slants and kept in refrigerator at $4^{\circ} \mathrm{C}$.

\section{Pathogenicity}

To prove Koch's postulate, the isolated pathogen were inoculated on healthy fruits and all the isolates tested were pathogenic on sorghum. However, the isolates behaved differently for the ability to produce disease 
symptoms on leaves. Isolate Et04 showed leaf blight symptoms after 6 days of inoculation. Typical symptoms of leaf blight developed on sorghum were similar to those described by Bunker (2006).

\section{Cultural and morphological variability}

The cultural characteristics of isolates are presented in Table 2 (Fig. 1.1 and 1.2). The following observations were made on Incubation period (days) for maximum growth, Colony colour, Pigmentation, Sporulation, Colony texture, Surface texture and Edge of colony.

\section{Incubation period (days) for maximum growth}

All the twenty isolates produced good growth on PDA, but the period taken by different isolates to completely cover the $9 \mathrm{~cm}$ petridish were different based on aggressiveness of the isolate. Among isolates Et04 shown lowest Incubation period of 6 days and Et15 shown highest Incubation period. In an average known to take 12 days of Incubation period to completely cover the $9 \mathrm{~cm}$ petridish.

\section{Colony colour}

The colony colour of fungus was recorded based on dominant spectral colour from Munsell's soil colour chart (1954), 12 days after incubation on PDA medium and the results are presented in Table 2. The colony colour varied from gray to black colour. Based on the colony colour all the twenty isolates were grouped in 6 categories i.e., Gray, dull grey, Dark grey, greenish grey, brown, and black. The Et10 (Badami), Et13(Dharwad M), Et18(Khanapur) and Et20(Belagavi) showed Black(2.5Y 2.5/1) colony colour wheres isolate Et04 shown Dark greyish to black (10YR 5/1) colony colour. The isolates Et02 from Vijayapur showed dark Greenish black
(5G 2/1) colony colour which was distinctly different from all other isolates. The isolates Et01 (Vijayapur), Et06 (Jamakhandi), Et12 (Dharwad AC), and Et19(Bailhongal) showed similar colony colour i.e Gray (2.5 Y 5/1), while very dark gray colony colour was observed in the isolates Et04, E08 and Et11 from Basavana Bagewadi $\mathrm{H}$, Bilagi and Hunagunda respectively. Et07 (Guledagudda), Et09 (Mudhol), Et16 (Kalaghatagi) and Et17 (Gokak) showed Dull grey colour. Et05 (Indi), Et14 (Navalagunda) and Et15 (Dharwad N) showed brown (10YR 7/2) coloured colony.

\section{Pigmentation}

Based on the pigmentation E. turcicum isolates were grouped into 4 groups i.e., Black, Bluish black, Greenish black and dark grey. The sorghum isolates Et06, Et07, Et11, Et17 and Et20 was in a distinctly different pigmentation i.e., bluish black (2.5/1 10P).

With regard to the isolate Et05, Et16 and Et19 showed greenish black (5G 2/1) pigmentation. The isolates like Et02, Et03, Et08, Et09, Et12, Et15 and Et18, showed black colour (16 YR 2/1) pigmentation whereas the isolates Et01, Et04, Et10, Et3 and Et14which were not having similar colony colour but with regard to pigmentation they showed the dark grey (2.5Y5/1) colour pigmentation (Fig. 1.2).

\section{Sporulation}

All the twenty E. turcicum isolates were classified into five groups based on the sporulation as mentioned in Table 2. Two isolates Et08 and Et14 produced excellent sporulation while the isolates Et04, Et13 and Et20 exhibited good sporulation and isolate Et01, Et03, Et12, Et15 and Et18 produced moderate sporulation, Whereas poor sporulation was noticed in the isolate Et02, Et05, Et06, Et10, Et11, Et16 and Et19 and no sporulation was found in Et07, Et09 and Et17 isolates. 
Table.1 Designation of Exserohilum turcicum isolates from different districts of Karnataka

\begin{tabular}{|c|c|c|c|c|}
\hline Sl. No & District & Location & Isolates identified & $\begin{array}{c}\text { Isolates } \\
\text { designation }\end{array}$ \\
\hline \multirow[t]{5}{*}{1} & \multirow[t]{5}{*}{ Vijayapur } & Hittinahalli & E. turcicum & Et01 \\
\hline & & Vijayapur & E. turcicum & Et02 \\
\hline & & $\begin{array}{l}\text { Basavana } \\
\text { Bagevadi }\end{array}$ & E. turcicum & Et03 \\
\hline & & $\begin{array}{l}\text { Basavana } \\
\text { Bagevadi }\end{array}$ & E. turcicum & Et04 \\
\hline & & Indi & E. turcicum & Et05 \\
\hline \multirow[t]{6}{*}{2} & \multirow[t]{6}{*}{ Bagalkot } & Jamakhandi & E. turcicum & Et06 \\
\hline & & Guledagudda & E. turcicum & Et07 \\
\hline & & Bilagi & E. turcicum & Et08 \\
\hline & & Mudhol & E. turcicum & Et09 \\
\hline & & Badami & E. turcicum & Et10 \\
\hline & & Hunagunda & E. turcicum & Et11 \\
\hline \multirow[t]{5}{*}{3} & \multirow[t]{5}{*}{ Dharwad } & Dharwad & E. turcicum & Et12 \\
\hline & & Dharwad & E. turcicum & Et13 \\
\hline & & Navalagunda & E. turcicum & Et14 \\
\hline & & Dharwad & E. turcicum & Et15 \\
\hline & & Kalaghatagi & E. turcicum & Et16 \\
\hline \multirow[t]{4}{*}{4} & \multirow[t]{4}{*}{ Belagavi } & Gokak & E. turcicum & Et17 \\
\hline & & Khanapur & E. turcicum & Et18 \\
\hline & & Bailhongal & E. turcicum & Et19 \\
\hline & & Belagavi & E. turcicum & Et20 \\
\hline
\end{tabular}


Table.2 Cultural characters of isolates Exserohilum turcicum on potato dextrose agar (PDA)

\begin{tabular}{|c|c|c|c|c|c|c|c|c|}
\hline Location & Isolate & $\begin{array}{l}\text { Incubation } \\
\text { period (days) } \\
\text { for max. } \\
\text { growth }\end{array}$ & $\begin{array}{l}\text { Colony } \\
\text { colour }\end{array}$ & Pigmentation & Sporulation & $\begin{array}{l}\text { Surface } \\
\text { texture }\end{array}$ & $\begin{array}{l}\text { Colony } \\
\text { texture }\end{array}$ & $\begin{array}{l}\text { Edge of } \\
\text { colony }\end{array}$ \\
\hline \multirow[t]{2}{*}{ Vijayapur } & Et01 & 9 & $\begin{array}{c}\text { Grey } \\
2.5 Y 5 / 1\end{array}$ & Dark grey & ++ & Fluffy & Ad pressed & $\begin{array}{l}\text { Highly } \\
\text { branched }\end{array}$ \\
\hline & Et02 & 8 & $\begin{array}{c}\text { Greenish } \\
\text { black 5G 2/1 }\end{array}$ & Black & + & Rough & $\begin{array}{c}\text { Moderately } \\
\text { wavy }\end{array}$ & Branched \\
\hline $\begin{array}{c}\text { Basavana } \\
\text { Bagevadi M }\end{array}$ & Et03 & 14 & $\begin{array}{c}\text { Black 2.5Y } \\
2.5 / 1\end{array}$ & Black & ++ & Rough & Cottony & $\begin{array}{l}\text { Sparsely } \\
\text { branched }\end{array}$ \\
\hline $\begin{array}{c}\text { Basavana } \\
\text { Bagevadi H }\end{array}$ & Et04 & 6 & $\begin{array}{c}\text { Dark greyish } \\
\text { to black } \\
\text { 10YR 5/1 }\end{array}$ & Dark grey & +++ & Smooth & Cottony & Branched \\
\hline Indi & Et05 & 9 & $\begin{array}{c}\text { Brown } \\
\text { 10YR 7/2 }\end{array}$ & Greenish black & + & Smooth & Wavy & $\begin{array}{l}\text { Sparsely } \\
\text { branched }\end{array}$ \\
\hline Jamakhandi & Et06 & 12 & $\begin{array}{c}\text { Grey } \\
2.5 Y 5 / 1\end{array}$ & Bluish black & + & Smooth & Wavy & Branched \\
\hline Guledagudda & Et07 & 9 & Dull grey & Bluish black & - & Fluffy & Ad pressed & Branched \\
\hline Bilagi & Et08 & 9 & Dark grey & Black & ++++ & Rough & $\begin{array}{c}\text { Moderately } \\
\text { wavy }\end{array}$ & $\begin{array}{l}\text { Sparsely } \\
\text { branched }\end{array}$ \\
\hline Mudhol & Et09 & 8 & Dull grey & Black & - & Smooth & Wavy & $\begin{array}{l}\text { Highly } \\
\text { branched }\end{array}$ \\
\hline Badami & Et10 & 11 & $\begin{array}{c}\text { Black 2.5Y } \\
2.5 / 1\end{array}$ & Dark grey & + & Fluffy & Wavy & $\begin{array}{c}\text { Highly } \\
\text { branched }\end{array}$ \\
\hline
\end{tabular}




\begin{tabular}{|c|c|c|c|c|c|c|c|c|}
\hline Location & Isolate & $\begin{array}{l}\text { No. of days } \\
\text { to cover plate }\end{array}$ & Colony colour & $\begin{array}{l}\text { Pigmentati } \\
\text { on }\end{array}$ & $\begin{array}{l}\text { Sporulati } \\
\text { on }\end{array}$ & $\begin{array}{l}\text { Colony } \\
\text { texture }\end{array}$ & $\begin{array}{l}\text { Surface } \\
\text { texture }\end{array}$ & $\begin{array}{l}\text { Edge of } \\
\text { colony }\end{array}$ \\
\hline Hunagunda & Et11 & 14 & Dark grey & $\begin{array}{l}\text { Bluish } \\
\text { black }\end{array}$ & + & Smooth & Cottony & Branched \\
\hline Dharwad AC & Et12 & 7 & Grey $2.5 Y 5 / 1$ & Black & ++ & Smooth & Ad pressed & $\begin{array}{l}\text { Sparsely } \\
\text { branched }\end{array}$ \\
\hline Dharwad M & Et13 & 9 & $\begin{array}{c}\text { Black 2.5Y } \\
2.5 / 1\end{array}$ & Dark grey & +++ & Rough & Cottony & Branched \\
\hline Navalagunda & Et14 & 11 & $\begin{array}{c}\text { Brown 10YR } \\
7 / 2\end{array}$ & Dark grey & ++++ & Rough & Cottony & Branched \\
\hline Dharwad N & Et15 & 15 & $\begin{array}{c}\text { Brown 10YR } \\
7 / 2\end{array}$ & Black & ++ & Fluffy & Cottony & $\begin{array}{l}\text { Sparsely } \\
\text { branched }\end{array}$ \\
\hline Kalaghatagi & Et16 & 8 & Dull grey & $\begin{array}{c}\text { Greenish } \\
\text { black }\end{array}$ & + & Fluffy & Wavy & Branched \\
\hline Gokak & Et17 & 11 & Dull grey & $\begin{array}{l}\text { Bluish } \\
\text { black }\end{array}$ & - & Rough & Cottony & $\begin{array}{l}\text { Highly } \\
\text { branched }\end{array}$ \\
\hline Khanapur & Et18 & 9 & $\begin{array}{c}\text { Black 2.5Y } \\
2.5 / 1\end{array}$ & Black & ++ & Rough & Ad pressed & $\begin{array}{l}\text { Sparsely } \\
\text { branched }\end{array}$ \\
\hline Bailhongal & Et19 & 14 & Grey $2.5 Y 5 / 1$ & $\begin{array}{c}\text { Greenish } \\
\text { black }\end{array}$ & + & Smooth & Cottony & $\begin{array}{l}\text { Highly } \\
\text { branched }\end{array}$ \\
\hline Belagavi & Et20 & 7 & $\begin{array}{c}\text { Black } 2.5 \mathrm{Y} \\
2.5 / 1\end{array}$ & $\begin{array}{l}\text { Bluish } \\
\text { black }\end{array}$ & +++ & Fluffy & Wavy & Branched \\
\hline
\end{tabular}

\section{Where,}

\begin{tabular}{|r|c|c|c|}
\hline \multicolumn{2}{|c|}{ Score } & Grade & Description \\
\hline 1. & ++++ & Excellent sporulation & $\geq 20$ conidia per microscopic field (40X) \\
\hline 2. & +++ & Good sporulation & $15-20$ spores/microscopic field (40x) \\
\hline 3. & ++ & Moderate sporulation & $10-15$ spores/ microscopic field $(40 \mathrm{x})$ \\
\hline 4. & + & Poor sporulation & $1-10$ spores/microscopic field $(40 \mathrm{x})$ \\
\hline 5. & & No sporulation & $<1$ spores $/$ microscopic field $(40 \mathrm{x})$ \\
\hline
\end{tabular}


Table.3 Effect of different solid media on the growth of E. turcicum (E004 strain)

\begin{tabular}{|c|c|c|}
\hline SI No. & Medium & Radial mycelial growth (cm) \\
\hline $\mathbf{1 .}$ & Potato dextrose agar & 7.35 \\
\hline $\mathbf{2 .}$ & Oat meal agar & 6.45 \\
\hline $\mathbf{3 .}$ & Czapeck's agar & 6.50 \\
\hline $\mathbf{4 .}$ & Malt extract agar & 5.25 \\
\hline $\mathbf{5 .}$ & Sabouraud's agar & 6.75 \\
\hline $\mathbf{6 .}$ & Yeast extract agar & 3.35 \\
\hline $\mathbf{7 .}$ & Richards' agar & 5.05 \\
\hline $\mathbf{8 .}$ & V-8 Agar & 3.00 \\
\hline & $\mathbf{S E}(\mathbf{m})$ & $\mathbf{0 . 0 5 7}$ \\
\hline & $\mathbf{C D}(\mathbf{P} \mathbf{0 . 0 1})$ & $\mathbf{0 . 1 6 7}$ \\
\hline & $\mathbf{C V}(\mathbf{\%})$ & $\mathbf{2 . 0 8 1}$ \\
\hline
\end{tabular}

Table.4 Morphological characters of isolates Exserohilum turcicum on potato dextrose agar (PDA)

\begin{tabular}{|c|c|c|c|}
\hline Isolate & $\begin{array}{c}\text { Size of conidia } \\
\text { length } \mathbf{x} \text { breadth }(\boldsymbol{\mu m})\end{array}$ & $\begin{array}{c}\text { No. of } \\
\text { septa } \\
\text { (Range) }\end{array}$ & $\begin{array}{c}\text { Chlamydospore } \\
\text { presence on 40 } \\
\text { DAI }\end{array}$ \\
\hline Et01 & $53.11 \times 12.34$ & $6-8$ & + \\
\hline Et02 & $63.18 \times 14.03$ & $6-9$ & - \\
\hline Et03 & $59.34 \times 14.74$ & $6-8$ & - \\
\hline Et04 & $66.41 \times 13.05$ & $6-8$ & - \\
\hline Et05 & $80.98 \times 15.16$ & $7-9$ & + \\
\hline Et06 & $81.61 \times 17.63$ & $8-10$ & - \\
\hline Et07 & $62.13 \times 13.2$ & $4-6$ & - \\
\hline Et08 & $56.71 \times 13.01$ & $5-7$ & - \\
\hline Et09 & $38.52 \times 11.91$ & $3-6$ & + \\
\hline Et10 & $87.13 \times 12.31$ & $7-10$ & - \\
\hline Et11 & $37.19 \times 11.21$ & $3-5$ & - \\
\hline Et12 & $53.40 \times 13.39$ & $6-7$ & - \\
\hline Et13 & $43.45 \times 12.65$ & $3-5$ & + \\
\hline Et14 & $33.92 \times 12.23$ & $3-4$ & - \\
\hline Et15 & $61.24 \times 11.43$ & $5-8$ & - \\
\hline Et16 & $65.38 \times 12.47$ & $4-9$ & - \\
\hline Et17 & $57.14 \times 13.14$ & $5-9$ & - \\
\hline Et18 & $68.93 \times 11.65$ & $4-6$ & - \\
\hline Et19 & $79.27 \times 13.11$ & $3-9$ & + \\
\hline Et20 & $45.82 \times 11.33$ & $5-8$ & + \\
\hline & & & \\
\hline
\end{tabular}




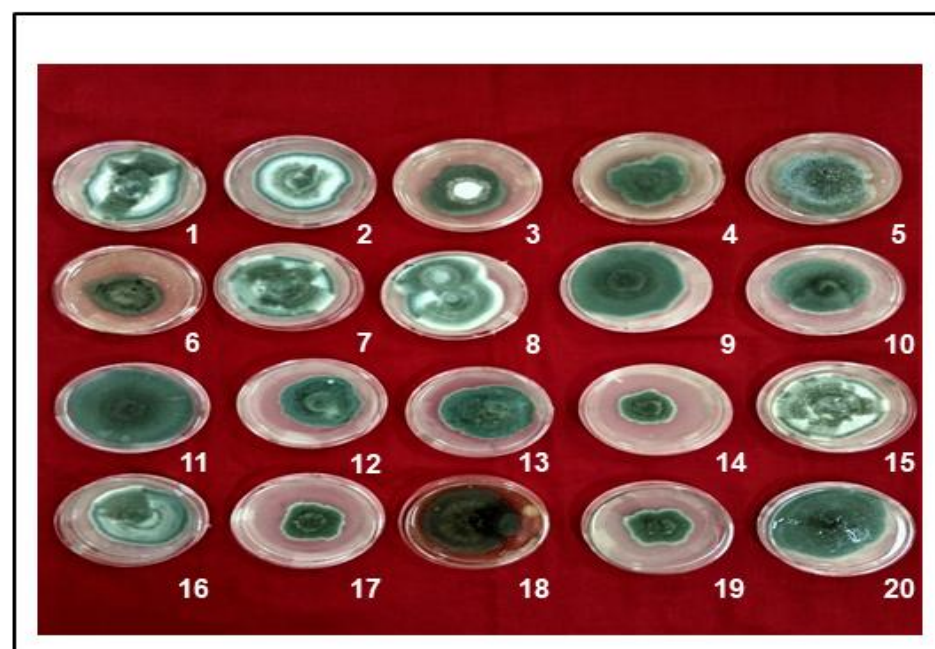

Figure 1.1: Growth of different isolates of Exserohilum turcicum on best supporting media (PDA)

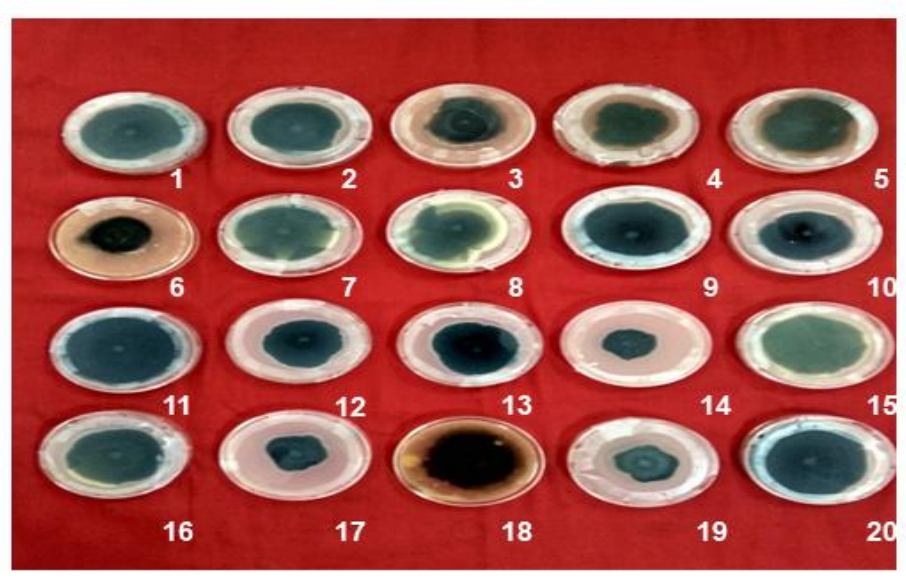

Figure 1.2: Pigmentation of different isolates of Exserohilum turcicum on best supporting media (PDA)

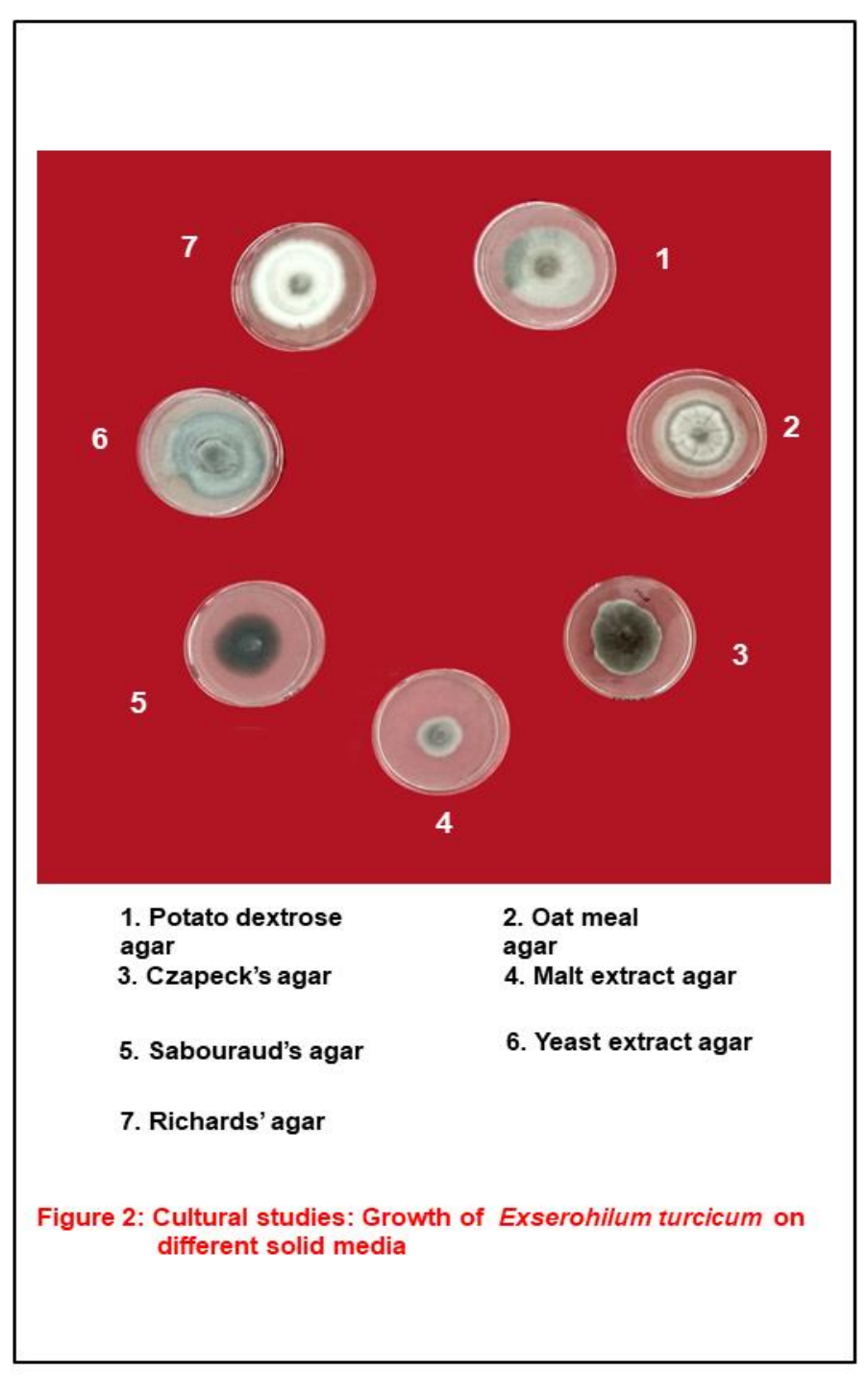




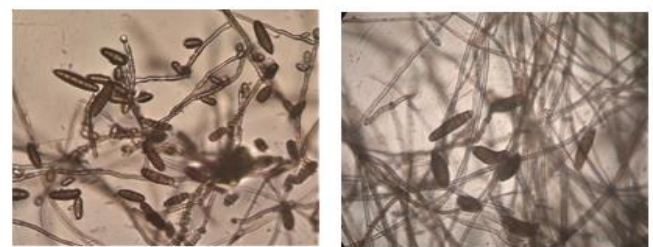

Et1 Et2

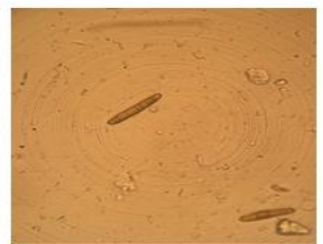

Et3

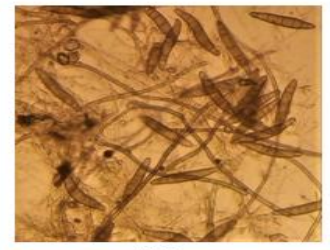

Et4

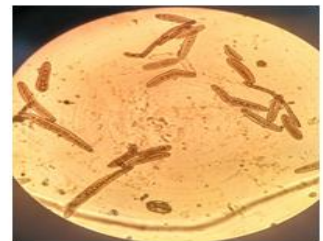

Et5

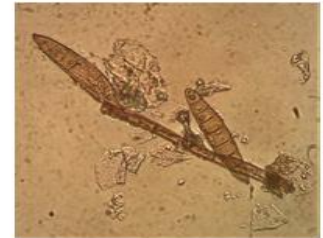

Et6

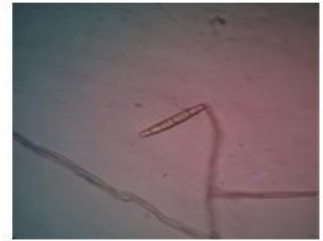

Et7

Figure 3.1: Conidial variability of E. turcicum isolates (40X) causing Turcicum leaf blight of sorghum

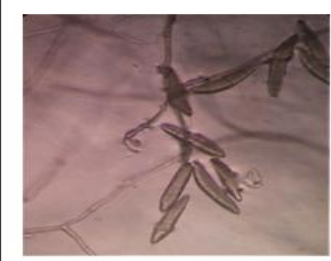

Et8

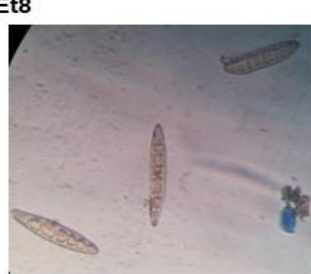

Et12

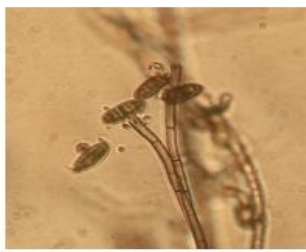

Et9

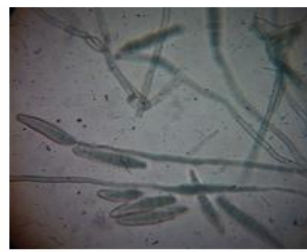

Et10

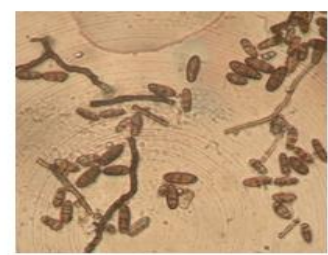

Et11

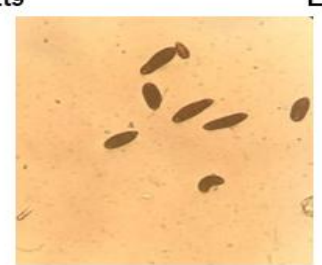

Et13

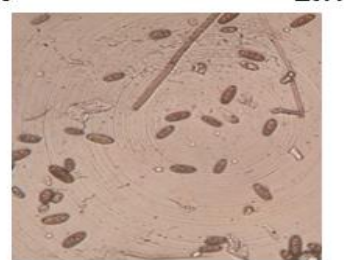

Et14

Figure 3.2: Conidial variability of E. turcicum isolates $(40 \mathrm{X})$ causing Turcicum leaf blight of sorghum
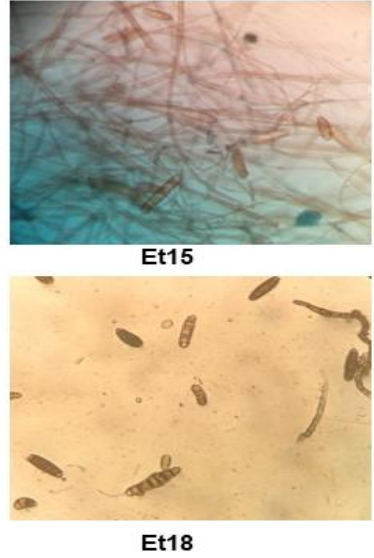
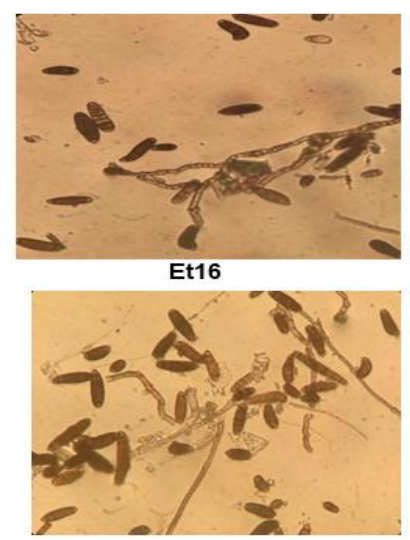

Et19

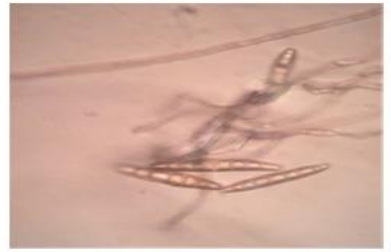

Et17

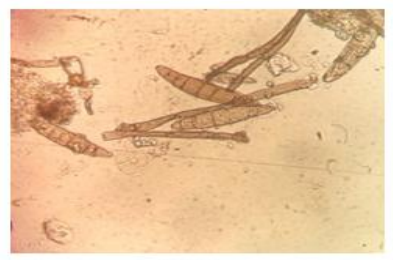

Et20

Figure 3.3: Conidial variability of E. turcicum isolates $(40 \mathrm{X})$ causing Turcicum leaf blight of sorghum 


\section{Surface texture}

On PDA majority of the isolates showed irregular shape. the isolates Et01, Et07, Et10, Et15, Et16, Et20 produced fluffy texture and Et02, Et03, Et08, Et13, Et14, Et17and Et18 produced rough texture whereas smooth surface texture produced by Et04, Et05, Et0, Et09, Et11, Et12 and Et19.

\section{Colony texture}

On PDA majority of the isolates produced distinct wavy zonation except isolate Et01, Et07, Et12 and Et18 which were produced ad pressed colonies. Et03, Et04, Et11, Et14, Et15, Et17 and Et19 produced cottony colony growth.

\section{Edge of colony}

The isolates when grown on PDA shown sparsely branched to highly branched edges of the colony.

The twenty isolates did differ in different prospect such as Incubation period (days) for maximum growth, Colony colour, Pigmentation, Sporulation, Colony texture, Surface texture and Edge of colony. Such variations have been reported by Gowda et al., (2010).

\section{Effect of different culture media on growth of different isolates of $E$. turcicum}

Nutrition plays an important role in growth of the fungus, the differential support of seven different culture media on growth of the virulent isolate $(\mathrm{Et04})$ of E. turcicum are presented in Table 3 (Fig. 2).

The virulent isolate (E04) showed significant variations in colony colour, colony texture, surface and topography, margin, lustre, sporulation and consistency in the media viz.,
PDA, Malt extract Agar, Saboraud's Medium, Richard's Medium, Czapek's dox medium, Yeast extract mannitol agar and Oat meal agar as shown in Table 3. The maximum average growth of the isolate (E04) was supported by PDA medium $(7.35 \mathrm{~cm})$ while the lowest diameter was recorded in $\mathrm{V}-8$ juice agar (3.00 $\mathrm{cm})$.

\section{Microscopic studies}

Twenty isolates shown three types of conidial shapes viz., curved, spindle and elongated. The size of the conidia averaged $93.97 \mu \mathrm{m}$ in length and $13.11 \mu \mathrm{m}$ in width. The number of septa was found to range from 3 to 11 (Table 4, Fig. 3.1 - 3.3). Conidia were observed in all the isolates except Et7, Et9 and Et17.

Among the isolates, conidia size was maximum in isolate Et10 $(87.13 \times 12.31 \mu \mathrm{m})$ with an average of 7-10 septation and minimum in isolate Et14 $(33.92 \times 12.23 \mu \mathrm{m})$ with 3-4 septation.

The results show similarities with the conidial measurement reported by Bunker et al., (2011). In conclusion, the present work on cultural and morphological variability of $E$. turcicum is the preliminary work which may be surely helpful for future studies on suitable management strategies of turcicum leaf blight of sorghum.

\section{Acknowledgement}

This study is financially supported by College of Agriculture Vijayapura (UAS Dharwad) through M.Sc. thesis programs (ID. No. PGS17AGR7575). Special thanks are conveyed to Dr. Arun R. Sataraddi (Farm Superintendent and Head, A.R.S. Bagalkot) for their constant encouragement and providing the resources to carry out the research work. 


\section{References}

Arun, G. K., Venkatesh, R. S. and Raghavan, G. S. (2009). Nutritional and rheological properties of sorghum. Int. J. Food Properties., 12: 55-69.

Bunker, R. N. and Mathur, K. (2010). Pathogenic and morphological variability of Exserohilum turcicum isolates causing leaf blight in sorghum (Sorghum bicolor). Indian J. Agric. Sci., 80(10): 888-892.

Bunker, R. N. and Mathur, K. (2006). Host range of leaf blight pathogen (Exserohilum turcicum) of sorghum. Indian Phytopath., 59(3): 370-372.

Gowda, K. T. P., Mallikarjuna, N., Kumar, G. B. S., Manjunath, B. and Kumar, B. R. (2010) Cultural and morphological variation in the isolates of Exserohilum turcicum the incitant of Turcicum leaf blight in maize. Environ. Ecol., 28(3): 1826-1830.

Harlapur, S. I., Kulkarni, M. S., Hegde, Y. and Kulkarni, S. (2007) Variability in Exserohilum turcicum (Pass.) Leonard and Suggs., causal agent of turcicum leaf blight of maize. Karnataka $J$. Agric. Sci., 20(3): 665-666.

Kadir, J., Sajili, M. H., Juraimi, A. S. and
Pertanika, N. S.(2008) Effect of Exserohilum monoceras (Drechslera) Leonard and Suggs on the competitiveness of Echinocloa crussgalli (L.) P. Beauv. J. Trop. Agric. Sci., 31(1): 19-26.

Lee, S. B., Kim, J. G., Kim, B. K., Han, H. J. and Yang, J. S.(1986). Studies on the qualitative and quantitative damage of suddangrass infected with leaf blight (Helminthosporium turcicum Pass.). J. Korean Soc. Grassland Sci., 6 (1): 6570.

Levy, Y.(1991) Variation in fitness among field isolates of Exserohilum turcicum in Israel. Plant Disease, 75: 163-166.

Sivanesan, A.(1986)Setosphaeria monoceras. CMI descriptions of pathogenic fungi and bacteria. pp. 886 .

Tarumoto, I., lsawa, K. and Watanabe, K.(1977) Inheritance of leaf blight resistance in sorghum-Sudan grass and sorghum, sorghum-hybrids. Japan J. Breeding., 27: 216-222.

Tosiah, S., Kadir, J., Sariah, M., Juraimi, A. S. and Soetikno, S. (2011). Efficacy of Exserohilum monoceras, a potential fungi for biocontrol of Echinochloa species. J. Trop. Agric. Food. Sci., 39(1): 117- 124.

\section{How to cite this article:}

Vinay, M. R. and Sataraddi, A. R. 2019. Studies on Cultural and Morphological Variability in Isolates of Exserohilum turcicum, Incitant of Turcicum Leaf Blight of Sorghum. Int.J.Curr.Microbiol.App.Sci. 8(12): 232-244. doi: https://doi.org/10.20546/ijcmas.2019.812.033 